\title{
Poetics of Understanding: Language Arts and Artistic Research
}

\author{
Alexander Damianisch
}

\begin{abstract}
:
What role does research play for the language arts? What is the significance of the language arts for research? This text attempts to sketch the outlines of this relation on the personal-general level and basis of selected poetics, based on statements by language artists. In essence, the thesis is that the potentials of the language arts can and should increasingly be integrated into the discourse of both research and artistic research for a better understanding.
\end{abstract}

The question arises ... as to whether the extent of these sectors on the plane assumed by us can be enlarged to any vital degree by the work of research. The achievements of the microscope, of the telescope, and of so many devices which increase the range of the senses upward and downward: do they not lie in another sphere altogether, since most of the increase thus achieved cannot be interpreted by the senses, cannot be 'experienced' in any real sense? It is, perhaps, not premature to suppose that the artist, who develops the five-fingered hand of his senses (if one may put it so) to ever more active and more spiritual capacity, contributes more decisively than anyone else to an extension of the several sense fields, only the achievement which gives proof of this does not permit of his entering his personal extension of territory in the general map before us, since it is only possible, in the last resort, by a miracle. ${ }^{1}$

RAINER MARIA RILKe, Primal Sound

\section{Search Becomes Research}

How does one learn to understand better? What role does language play in that? When is the moment when its use becomes a tool for art and research?

1 Rainer Maria Rilke, Primal Sound (1919), in:Rodin and Other Prose Pieces, translated by G. Craig Houston. London: Quartet 1986, pp. 128-130: here p. 130. 
Everything begins with hearing, seeing, and reading. First, the goals are close at hand: the lettering on shops, road maps, comic books, headlines in magazines and, of course, what is written in school textbooks, instructions, explanations, and assignments. Follow toy catalogues, lists of inventories of objects and the possibilities they embody. One studies the lists to find the right object. ${ }^{2}$ One learns what is worthwhile, what one wants to have; one begins to imagine. This is the first part of the stage in which one uses language by gathering writing via reading. Then maybe one starts to become interested in dinosaurs, in tennis players, in a singer and wants to keep going. One learns to know, in addition to what one receives, what one is told or what happens on other paths. The goal is to understand in order to deduce how everything is or could be. The search becomes research; this is what Rainer Maria Rilke calls "the extension of territories."3 Friedrich Kittler wrote: "Rilke draws conclusions more radical than all scientific boldness." ${ }^{4} \mathrm{He}$ extends the territories of understanding.

\section{Questioning of Phenomena}

The interpretation of objects collected by Rilke in the group of New Poems is an example of the questioning of phenomena with regard to their potential. It concerns the focused concentration on phenomena. Interestingly, this is done in response to Rilke'sreading ${ }^{5}$ of Auguste Rodin's ${ }^{6}$ and Paul Cézanne's ${ }^{7}$ work. Apropos of the desire to find a way of working, a method, that makes new seeing and shaping possible, Rilke explicitly developed a detached and analytical working

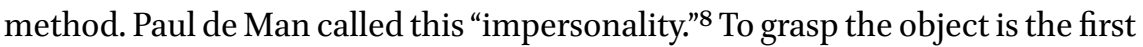

2 There is a known and well researched tendency in literature that lists and/or inventories are a well-considered technique to pinpoint the given and thereby develop new ways of understanding. (Cf. Günter Eich, Inventur, in: Günter Eich, Abgelegene Gehöfte. Mit vier Holzschnitten von Karl Rössing. Frankfurt am Main: Verlagsbuchhandlung, 1948, pp. 42-43.)

3 Rilke (1986), Primal Sound, p. 130.

4 Friedrich Kittler, Gramophone, Film, Typewriter, translated by Geoffrey Winthrop-Young and Michael Wutz. Stanford, CA: Stanford University Press, 1999, p. 42.

5 In a more literal sense, it would be more consequent to use the word 'seeing' here, especially in relation to the concept of seeing in Malte Laurids Brigge (1910).

6 Rainer Maria Rilke, Auguste Rodin (1903), translated by G. Craig Houston. Mineola, NY: Dover Publications, 2006.

7 Cf. Rainer Maria Rilke, Letters on Cézanne (1952), translated by Joel Agee, ed. by Clara Rilke. New York, NY: North Point Press, 2002.

8 Cf. "It will take the long labors of Malte and of The New Poems to reconquer the impersonality" (Paul de Man, Allegories of Reading. Figural Language in Rousseau, Nietzsche, Rilke, and Proust. New Haven, CT, London: Yale University Press, 1979, p. 33). 
step towards collecting. As Rilke so succinctly and appropriately said of the experiences of Malte Laurids Brigge in the city: "Have I said it before? I am learning to see." ${ }^{\prime 9}$ This means he is learning to read the things and to understand anew.

\section{The Lure of Boundaries}

In a next personal step, correlations begin to show. Individuals move closer in specific relationships with each other; steps become paths; pictures become films. Relations are perceived. Stories are read to us, then the 'I' and 'you,' the personal, become more and more exciting. The lure of boundaries starts to play a role. You slide into different states. You surf on unknown waves. The temptations create the transgression, the transgression the temptations. Helga Nowotny has placed inquisitiveness in the centre of her epistemic theories. ${ }^{10}$

Daniel Kehlmann, for example, still recounts his influential early reading of Jeremias Gotthelf's The Black Spider..$^{11}$ The fascination of the unfamiliar, the uncanny, is evident. ${ }^{12}$ You are tempted to move into these worlds. By reading, you discover what else you would not have learned—and also what you cannot know. You explore unknown areas, practise making an attempt. The explicit process of surveying unknown terrain is also the focus of Christoph Ransmayer's work. ${ }^{13}$ Especially Atlas of an Anxious Man is a fine example in this sense. The 'man' is already labelled as 'anxious,' and his goal of developing an 'atlas' is named in the very title of Ransmayer's text collection. He wants to map the challenging area. Another example for this is Kehlmann's novel, Measuring the

$9 \quad$ Rainer Maria Rilke, The Notebooks of Malte Laurids Brigge (1910), translated by Stephen Mitchell. New York, NY: Vantage 1990, p. 6.

10 Cf. Helga Nowotny, Unersättliche Neugier: Innovation in einer fragilen Zukunft. Berlin: Kadmos, 2005.

11 Cf. Daniel Kehlmann, Kommt, Geister. Frankfurter Vorlesungen. Reinbek: Rowohlt, 2015.

12 Ferdinand Schmatz talks about the beginning of his relationship with literature in relation to his so-called "Kafka literature phase," he explains: "[T] he abstraction, and what existed behind it, I found extremely attractive. Now I would call it erotic. There was such a tension between individual and dependence and desire, which has not been fulfilled, and sometimes is, or nearly is." This, among other things, was Ferdinand Schmatz's response to the question of how he went "from reader to writer." (Ferdinand Schmatz, Auf SÄTZE!: Essays zur Poetik, Literatur und Kunst. Berlin: De Gruyter 2016, p. 314.)

13 The following titles are listed by way of an example: Die Schrecken des Eises und der Finsternis (The Terrors of Ice and Darkness). Wien, Munich: Brandstätter, 1984; Morbus Kitahara (The Dog King). Frankfurt am Main: S. Fischer, 1995; Der Weg nach Surabaya (The Way to Surabaya). Frankfurt am Main: S. Fischer, 1997; Der fliegende Berg (The Flying Mountain). Frankfurt am Main: S. Fischer, 2006; Atlas eines ängstlichen Mannes (Atlas of an Anxious Man). Frankfurt am Main: S. Fischer, 2012. 
World, ${ }^{14}$ again already the title itself sets the stage. Different, but in comparison also relevant is Marlene Haushofer's The Wall. This novel, again, questions the territory of the possible in a very clear literal sense, describing the limitations of the woman protagonist as being cut off from society in the wild, without any possibility of expanding her territory of action back to relevance again, to put it short. What appears in this case as the real issue is the discourse without relations, one could say the numb discourse that is the stage and in many cases the very field and challenge of language arts and research.

\section{Extension of the Sense Fields}

The need for a simple visual, cartographic order is the subject of criticism in the conclusion of Rilke's text Primal Sound. The critique is directed against the presumptuousness of established research areas. Rilke demands respect for the artist's activity towards "an extension of the several sense fields," ${ }^{15}$ whether through the use of language or other matter. What is not understood, should be visited-not so much to measure it, but to convey it.

Quite some authors of the recent literary history are travelling on the boundaries of these sense fields. The novel of Michel Houellebecq's, The Map and the Territory, is of relevance here because the protagonist does nothing but conquer the space with his art pieces. ${ }^{16}$ Even writers like Marlen Haushofer play a particular role in this journey, and another in the slightly vivid context of German literature is Elfriede Jelinek. They are two excellent examples of authors who process and bring to perception radical reflexes. Their representations of the invisible present the violence that had long been neglected and could only be made visible through its application to the map. Having become identifiable, the violence can potentially be mastered in relation to the given discourse without relations. It can become an integral part of the map of social awareness as an object of examination and analysis for better understanding.

\section{The Possibility of the Familiar Becoming Alien}

Regarding understanding, the relation between the familiar and the unknown, one might connect the language arts themselves as research with the idea of

14 Daniel Kehlmann, Measuring the World, translated by Carol Brown Janeway. New York, NY: Pantheon Books, 2005.

15 Rilke (1986), Primal Sound, p. 130.

16 Cf. Michel Houellebecq, The Map and the Territory, translated by Gavin Bowd. New York, NY: Knopf, 2011. 
science fiction. For there is always science that threatens to explain the field of research as such. The term science fiction has a peculiar sound. It is not just the unimaginable that can be heard here. Concretely, one must think of knowledge (apropos science) on the one hand and idea (apropos fiction) on the other: the known, held by knowledge, experiences perspectives in a next stage. With this twist, we have arrived poetologically, where the language arts can be understood as artistic research.

Let us remember Heinrich von Kleist's proposition: "People could be divided into two classes: those who understand a metaphor, and 2) those who understand a formula. Those who understand both are too few; they do not comprise a class." ${ }^{\prime 7}$ In the metaphor the known is loaded with ideas; these ideas are transmitted. In the formula, the unknown is put into frameworks by means of an explanatory apparatus. To test, prove, or disapprove. Can this be considered as conducting an experiment?

The example of the atlas, as already mentioned apropos of Ransmayer, provides such a methodical framework. It enables the measurement of catastrophic or at least open-ended events in a strict order in which findings are made communicable. Understanding wants to go beyond what is offered, also methodologically, what is out there or what could be, whether invented or genuinely tempting. The possibility that the familiar becomes alien and the development of tools to support this are of interest. In the desire for better understanding, reading will begin to become a way to penetrate past diversions into possibilities.

\section{Research is Taking Shape}

From early on, language becomes writing to leave traces and to challenge us via text. The search for what one has discovered leads to one's own attempts to set things down. One develops style. One begins to imbue the instrument of language with experience. The Language becomes its path, which one slowly feels and shapes retrospectively. It is a way to share and develop understanding. The practice of the language arts takes shape and reformulates itself anew, like the horizon, which is always created anew on approach. This is the moment when the understanding of the shaping of reality and its possibilities becomes stronger than the spontaneous perception of what you have learned to recognise as real. Research is taking shape. This is the case when a method is developed from the power of mastering language, which enables one to better

17 Heinrich von Kleist, Fragmente, in: Sämtliche Werke und Briefe, zweibändige Ausgabe in einem Band, ed. by Helmut Sembdner. Munich: DTV, 2001, p. 338. 
understand and recognise when new and different things emerge from theformal and content-related-probing of boundaries. This is precisely what Rilke did with the New Poems and, as an author, his character Malte implemented through his notebooks.

Content-wise, what you want to understand better can be anything. Everything is available, and with this instrument it is possible to extend everything methodically, to expand the field, and thereby begin to create, to produce, to develop. Ernst-Wilhelm Händler, for example, attempted to analyse the novel as such a methodological instrument with his essay Versuch über den Roman als Erkenntnisinstrument. ${ }^{18} \mathrm{~A}$ business school graduate, entrepreneur, and author with a lively stream of publications, Händler has repeatedly produced texts that present an expedient documentary of reality experiments, as Hermann Broch had previously done-or Gustave Flaubert. In such cases, the language arts in novel form help to understand, as Pierre Bourdieu demonstrated about Flaubert. ${ }^{19}$ On another occasion, Bourdieu even identifies with Karl Kraus and sees in his work the sociological experiment ideally developed. ${ }^{20}$ This provides another example where language arts have succeeded in inserting impassible terrain into a new sense field on our map. It is of great interest that the influential relation between Kraus and Rilke is a vital, crucial bridge that opened up a path for such developments. ${ }^{21}$

18 Ernst-Wilhelm Händler, Versuch über den Roman als Erkenntnisinstrument. Frankfurt am Main: S. Fischer, 2014.

19 Pierre Bourdieu's analysis in The Rules of Art provides an ideal example: based on a novel-Sentimental Education by Gustave Flaubert-it is shown precisely how clever the language arts are and how capably they can make things more sympathetic to us. Cf. Pierre Bourdieu, The Rules of Art: Genesis and Structure of the Literary Field, translated by Susan Emanuel. Stanford, CA: Stanford University Press, 1996.

20 In the first paragraph of Satz und Gegensatz, Pierre Bourdieu writes: "The philosophical tradition and its claim to call common sense into question, to the point of its ultimate logical consequences, I have directed the scientifically acquired instruments of objectification against ... the world of the intellectuals themselves, a world which still leaves the most critical critics untouched, with the exception of perhaps one Karl Kraus, whose provocations partly corresponded to the real sociological experiments through which the seemingly most obvious indifference and disinterestedness can be unmasked." (Pierre Bourdieu, Satz und Gegensatz. Über die Verantwortung des Intellektuellen. Berlin: Klaus Wagenbach, 1989, p. 7.)

21 The issue of the Fackel published by Karl Kraus with the war-critical essay "In this great time" of December 5, 1914, had been sent by Rainer Maria Rilke to his friend Lou Andreas-Salomé, with the enclosed remarks in parenthesis: "The last consequences of the impossibilities, in which we have lived. The fate will be precise ..." (Rainer Maria Rilke, Briefwechsel: Rainer Maria Rilke - Lou Andreas Salome, ed. by Ernst Pfeiffer. Frankfurt am Main: Insel, 1989, p. 585.) 


\section{One Prize for Two}

At this point, it should be pointed out again that art and science do not resist each other in their practice, but both exist together. This assertion resonates with Hans-Jörg Rheinberger's finding that the differentiation between art (poetology) and science (epistemology) was recent. He writes:

The fact that the sciences and the arts have historically created at least meta-stable, separate realms must at least be noted, even if this separation did not always and everywhere exist, and if perhaps it will not always remain so. It might well be, however, that this separation is a secondary effect - collateral damage, so to speak — of the respective stabilization at the level of social negotiation, communication and distribution, and is due less to the conditions of the creation of epistemic and artistic values. What we can do is to stake out a discursive space in which it is possible for scientists and artists to examine each other's hands, based less on what they say than on what they do when they practice their craft. ${ }^{22}$

Again, we are staking out a space; again, we are travelling together on a map.

If you leap back in time, one example of a tradition which does not know of a separation of research into art and science can be found in the "beautiful science." That is how the language arts were called by Johann Joachim Eschenburg in his Preliminaries of a Theory and Literature of the Beautiful Sciences $(1783) \cdot{ }^{23}$ It would be time to review this designation for its suitability in current artistic research. It is about form, finding the right form, precisely by means of language-artistic methods and poetics. On the one hand, it is a matter of normative descriptions in the sense of established rules; on the other hand, it is recording descriptive attempts to find what is happening when poetic work is done.

As a winning thesis in the context of artistic research, it is essential to maintain that if you engage in something without knowing, you are best supported by better understanding. In the set of possible parameters, there is a possible

22 Hans-Jörg Rheinberger, Episteme zwischen Wissenschaft und Kunst. Unpublished manuscript to a paper given at the IFK: Internationales Forschungszentrum Kulturwissenschaften, Vienna, 4 Mar. 2015, p. 20.

23 Johann Joachim Eschenburg, Entwurf einer Theorie und Literatur der schönen Wissenschaften (1783), in: Lyriktheorie. Texte vom Barock bis zur Gegenwart, ed. by Ludwig Völker. Stuttgart: Reclam, 2000. Text (1783; abridged) with introduction and commentaries: pp. 105113; also availableat:https://www.uni-due.de/lyriktheorie/texte/1783_b4eschenburg .html\#gliederung3, date of access: 17 Sept. 2018. 
formation, a mixture of time and space, idea and matter, ability and impulse, in which understanding becomes possible. Art and science have developed into two central sediment fields. The conscious step of focusing on how these two fields are constituted is essential. On the other hand, it is crucial to address dynamics that are fundamental in what is deemed a researching approach.

\section{Emergent and Transgressive for the Sake of Understanding}

Poetic work is the core of artistic work in dealing with language, a dynamic, vital force, a permanent unrest of meaning. This unrest is doubly charged; it is the standard denominator when you attempt to recapitulate what unites art and science. 'Art' encompasses all practice currently being negotiated in the field, including the performing arts and, naturally, visual arts, applied arts and liberal arts. It is always a matter of connecting levels of perception and form, the latter being the complementary of research in the arts, particularly in comparison to research in the sciences. On the scientific side, it is above all the reflection which can explicitly be called an idiosyncrasy, from which art now benefits as research. It is, therefore, perception, reflection, and formation that act in conjunction.

If we now take poetry as an effective force and recall the origin of the word, that is, its meaning of creating or shaping, from the Greek poieĩn-meaning production - then the broader meaning of the concept is shown. The career of the concept of poetry, understood not as a poetic catalogue of governing forms, but as a possibility of linguistically shaping things, is a massively moving one; we move it further and perhaps return to a new meaning and relevance. There are two different paths in literary studies: the first refers primarily to the text, the second to the context. Both paths attempt to open up meaning and to better understand what texts signify and what meanings they try to bring to understanding. Often, this is also broadened by the question of relevance placed on it, measuring how importantly we should take literature and its study. Remember that Theodor W. Adorno referred to style as the "habitus of language." ${ }^{24}$

In conclusion to this text and regarding the question of who among the peers is the heir and who the donor, the 'research' in 'artistic research' or the 'language' in the 'language arts,' I would say that 'art' is the solution. Art never existed without a research praxis and reflective quality related to language; literature and artistic research have always interacted, emergent and transgressive

24 Theodor W. Adorno, Noten zur Literatur. Frankfurt am Main: Suhrkamp, 1998, p. 45. 
for the sake of a better understanding, etc. Thank you for sharing my personal "extension of" our "territory" (Rilke).

\section{Bibliography}

Adorno, Theodor W., Noten zur Literatur. Frankfurt am Main: Suhrkamp, 1998.

Bourdieu, Pierre, Satz und Gegensatz. Über die Verantwortung des Intellektuellen. Berlin: Klaus Wagenbach, 1989.

Bourdieu, Pierre, The Rules of Art: Genesis and Structure of the Literary Field, translated by Susan Emanuel. Stanford, CA: Stanford University Press, 1996.

Eschenburg, Johann Joachim, Entwurf einer Theorie und Literatur der schönen Wissenschaften (1783), in: Lyriktheorie. Texte vom Barock bis zur Gegenwart, ed. by Ludwig Völker. Stuttgart: Reclam, 2000, pp. 105-113. [Also available at: https://www.uni-due .de/lyriktheorie/texte/1783_b4eschenburg.html\#gliederung3, date of access: 17 Sept. 2018.]

Eich, Günter, Abgelegene Gehöfte. Mit vier Holzschnitten von Karl Rössing. Frankfurt am Main: Verlagsbuchhandlung, 1948.

Händler, Ernst-Wilhelm, Versuch über den Roman als Erkenntnisinstrument. Frankfurt am Main: S. Fischer, 2014.

Houellebecq, Michel, The Map and the Territory, translated by Gavin Bowd. New York, NY: Knopf, 2011.

Kehlmann, Daniel, Kommt, Geister. Frankfurter Vorlesungen. Reinbek: Rowohlt, 2015.

Kehlmann, Daniel, Measuring the World, translated by Carol Brown Janeway. New York, NY: Pantheon Books, 2005.

Kittler, Friedrich, Gramophone, Film, Typewriter, translated by Geoffrey Winthrop-Young and Michael Wutz. Stanford, CA: Stanford University Press, 1999.

Kleist, Heinrich von, Fragmente, in: Heinrich von Kleist Sämtliche Werke und Briefe, zweibändige Ausgabe in einem Band, ed. by Helmut Sembdner. Munich: DTV, 2001.

Nowotny, Helga, Unersättliche Neugier: Innovation in einer fragilen Zukunft. Berlin: Kadmos, 2005.

Man, Paul de, Allegories of Reading. Figural Language in Rousseau, Nietzsche, Rilke, and Proust. New Haven, CT, London: Yale University Press, 1979.

Rheinberger, Hans-Jörg, Episteme zwischen Wissenschaft und Kunst. Unpublished manuscript to a paper given at the IFK: Internationales Forschungszentrum Kulturwissenschaften, Vienna, 4 Mar. 2015.

Rilke, Rainer Maria, Primal Sound (1919), in: Rodin and Other Prose Pieces, translated by G. Craig Houston. London: Quartet, 1986, pp. 128-130.

Rilke, Rainer Maria, Briefwechsel: Rainer Maria Rilke - Lou Andreas Salome, ed. by Ernst Pfeiffer. Frankfurt am Main: Insel, 1989. 
Rilke, Rainer Maria, The Notebooks of Malte Laurids Brigge (1910), translated by Stephen Mitchell. New York, NY: Vantage, 1990.

Rilke, Rainer Maria, Letters on Cézanne (1952), translated by Joel Agee, ed. by Clara Rilke. New York, NY: North Point Press, 2002.

Rilke, Rainer Maria, Auguste Rodin (1903), translated by G. Craig Houston. Mineola, NY: Dover Publications, 2006.

Schmatz, Ferdinand, Auf SÄTZE!: Essays zur Poetik, Literatur und Kunst. Berlin: De Gruyter, 2016. 